Federal Reserve Bank of Dallas

Globalization and Monetary Policy Institute

Working Paper No. 179

http:// www.dallasfed.org/ assets/ documents/ institute/ wpapers/2014/ 0179.pdf

\title{
The Role of Direct Flights in Trade Costs ${ }^{*}$
}

\author{
D emet Yilmazkuday \\ Florida International University \\ Hakan Yilmazkuday \\ Florida International University
}

May 2014

\begin{abstract}
The role of direct flights in trade costs is investigated by introducing and using a micro price data set on 49 goods across 433 international cities covering 114 countries. It is shown that having at least one direct flight reduces trade costs by about 1,400 miles in distance equivalent terms, while an international border increases trade costs by about 14,907 miles; hence, the positive effects of having at least one direct flight between any two cities can compensate for about $10 \%$ of the negative effects of an average international border. Trade costs also decrease with the number of direct flights: on average, one direct flight reduces trade costs by about 305 miles in distance equivalent terms, which corresponds to $7 \%$ of the average distance and can compensate for about $2 \%$ of the negative effects of an average international border. The results are shown to be robust to alternative empirical strategies.
\end{abstract}

JEL codes: F15, F31

\footnotetext{
* Demet Yilmazkuday, Department of Economics, Florida International University, Miami, FL 33199. 305348-2316. Demet.yilmazkuday@fiu.edu Hakan Yilmazkuday, Department of Economics, Florida International University, Miami, FL 33199. 305-348-2316. Hakan.yilmazkuday@fiu.edu. The views in this paper are those of the authors and do not necessarily reflect the views of the Federal Reserve Bank of Dallas or the Federal Reserve System.
} 


\section{Introduction}

The increase in air transportation/travel due to the technological development in jet aircraft engines has led to the improvement of global market integration significantly since World War II. This improvement has been partly achieved by the increase in air shipment due to lower air transportation costs, ${ }^{1}$ and partly due to the face-to-face business meetings that overcome informational asymmetries in international trade. ${ }^{2}$ Besides the obvious role of air transportation in the integration of the traded goods markets, air travel of individuals has also contributed to the integration of non-traded goods markets, such as the housing market and the service sector. ${ }^{3}$ Therefore, there is no doubt that air transportation/travel has significantly contributed to welfare-improving globalization through reducing trade costs between regions/countries.

Within this picture, direct flights have gained more importance, because they provide the cheapest and fastest air transportation/travel. For example, Alderighi and Gaggero (2012) have found that the elasticity of exports to direct flights is about 10\%. Similarly, Micco and

\footnotetext{
${ }^{1}$ Hummels (2007) shows that by the year of 2000, air shipments were representing a third of the value of U.S. imports and more than half of U.S. exports with countries outside North America. Similarly, again in 2000, excluding land neighbors, the air share of import value was more than 30 percent for Argentina, Brazil, Colombia, Mexico, Paraguay, and Uruguay.

${ }^{2}$ As Cristea (2011) and Poole (2013) have shown, business travel helps to overcome informational asymmetries in international trade by generating international sales in the form of new export relationships.

${ }^{3}$ For example, Ley and Tutchener (2001) show how house prices in Canadian cities are strongly associated with overseas tourism. Moreover, service sectors such as medical tourism have benefited from the existence of direct flights between countries, as discussed in Bookman and Bookman (2007), Herrick (2007), and Helble (2011).
} 
Serebrisky (2006) have shown that Open Skies Agreements between countries, which allow airlines to operate direct flights internationally, reduce air transport costs by $9 \%$ and increase by $7 \%$ the share of imports arriving by air. Moreover, studies such as Bel and Fageda (2008) have found that the availability of direct flights has a large influence on the location of large firms' headquarters, which is another factor facilitating trade. ${ }^{4}$

This paper attempts to measure the effects of direct flights on overall trade costs between cities (in distance equivalent terms) by introducing and using a micro price data set on 49 goods across 433 international cities covering 114 countries. In the benchmark specification, following Eaton and Kortum (2002), together with other studies in which consumers search for the minimum price across locations, we define intercity trade costs as the maximum price difference (i.e., the maximum of deviations from the Law of One Price) across goods between two cities; for any city pair for which we compare micro prices, we also search for airports within 50 miles to check whether they have any direct flights between each other.

The benchmark results show that having at least one direct flight corresponds to a reduction in trade costs by about 1,400 miles in distance equivalent terms, on average; this is about one third of the average distance between the cities in the sample that is about 4,551 miles. Due to having both international and intranational city pairs, we also investigate the role of an international border in trade costs: it is found that the average international border increases trade costs by about 14,907 miles in distance equivalent terms, which is about triple the average distance. In other words, the positive effects of having at least one direct flight between any two cities can compensate for about $10 \%$ of the negative effects

\footnotetext{
${ }^{4}$ Regarding the importance of time spent in transportation, Hummels and Schaur (2013) estimate that each day in transit is equivalent to an ad-valorem tariff of $0.6 \%$ to $2.3 \%$.
} 
of an average international border. Trade costs are also shown to be decreasing with the number of direct flights: the results show that one direct flight reduces trade costs by about 305 miles, which is about $7 \%$ of the average distance; therefore, the positive effects of one direct flight between any two cities can compensate for about $2 \%$ of the negative effects of an average international border.

For robustness, we consider many alternative empirical strategies. In order to measure trade costs, for instance, we alternatively follow Borraz et al. (2012) who have suggested using 80 th, 90 th or higher percentiles of micro price differences in order to reduce the severity of measurement errors in prices; on the other hand, we also follow Eaton and Kortum (2002) by using the second maximum of the price difference between cities. Since direct flights can be used for the air transportation of goods (i.e., for the market integration of traded goods) or for the air travel of individuals (i.e., the market integration of non-traded goods, such as housing and services, especially through tourism), we also consider the price difference between cities for both traded and non-traded goods in our sample. Finally, while searching for a direct flight between any two cities, we consider airports within 25, 100 and 200 miles of the city centers. In all of these alternative empirical strategies, we find very similar results in which the effect of direct flights on trade costs is always negative and significant.

The rest of the paper is organized as follows. The next section introduces the empirical methodology used to measure trade costs and details of the regression analysis. Section 3 depicts the data and descriptive statistics. Section 4 reveals the empirical results. Section 5 concludes. 


\section{Empirical Methodology}

\subsection{Measuring Trade Costs}

Data for trade costs are either non-existing or not covering the globe. ${ }^{5}$ Accordingly, studies such as by Eaton and Kortum (2002), Simonovska and Waugh (2014), among many others, have considered disaggregate price information across countries to measure trade costs. For example, in Eaton and Kortum (2002), given a pair of countries, the maximum price difference across goods is used as a measure of trade costs. In order to understand the logic behind this, consider the following arbitrage condition for the same good between any two locations:

$$
\frac{P_{i}^{g}}{P_{j}^{g}} \leq \tau_{j i}
$$

where $P_{i}^{g}$ is the price of good $g$ in location $i, P_{j}^{g}$ is the price of good $g$ in location $j$, and $\tau_{j i}$ represents the gross multiplicative trade costs from location $j$ to location $i$. When traded goods are considered, this expression literally means that importing good $g$ from location $j$ is more costly compared to the already-available price in location $i$; therefore, this is an expected situation in the equilibrium after arbitrage opportunities are taken (i.e., after possible trade is achieved). When non-traded goods are considered, this expression means that travelling from city $i$ to city $j$ to consume good $g$ is more expensive than consuming the same good in city $i$; the same arbitrage conditions are implied as for traded goods. Therefore,

\footnotetext{
${ }^{5} \mathrm{An}$ exception is the data set for the U.S. international trade that can be obtained from http://dataweb.usitc.gov/. Nevertheless, even this detailed data set covers only the calculated duties and the cost of all freight, insurance, and other charges incurred; it does not cover, for instance, trade costs due to search frictions or time to ship.
} 
in our empirical investigation, below, we will consider the implications for both traded and non-traded goods.

The symmetric version of Equation 1 also holds with an inequality:

$$
\frac{P_{j}^{g}}{P_{i}^{g}} \leq \tau_{i j}
$$

When trade costs are symmetric (i.e., when $\tau_{j i}=\tau_{i j}$ ), the last two inequalities can be combined in log terms as follows:

$$
\left|p_{i}^{g}-p_{j}^{g}\right| \leq \log \tau_{i j}
$$

where $|\cdot|$ is the absolute operator, $p_{i}^{g}=\log P_{i}^{g}$, and $p_{j}^{g}=\log P_{j}^{g}$. The main point is that, when the maximum (i.e., the upper bound) of the left hand side is considered, the last inequality turns into an equality. For example, Eaton and Kortum (2002) consider the maximum of the left hand side as the maximum price difference across goods between two locations, which can be summarized as follows:

$$
\log \tau_{i j}=\max _{g}\left\{\left|p_{i}^{g}-p_{j}^{g}\right|\right\}
$$

We follow this definition of trade costs in our benchmark results.

As mentioned by Eaton and Kortum (2002) and Borraz et al. (2012), however, the maximum price difference across goods is sensitive to the possibility of measurement errors in the price data. Accordingly, Eaton and Kortum (2002) have considered the second maximum price difference across goods, while Borraz et al. (2012) have considered alternative percentiles (e.g., 80th, 90th, etc.). Therefore, besides our benchmark case defined as Equation 2 , for robustness, we will also consider these alternative measures in our investigation. 


\subsection{Regression Analysis}

Once trade costs are obtained (as described in the previous subsection), we are interested in the effects of having direct flights between cities. Since we have data for the exact number of direct flights between cities, we will consider two alternative approaches.

In the first specification, we consider the effects of having at least one direct flight between cities. Accordingly, the following regression will be used (where the superscripts represent the specification):

$$
\log \tau_{i j}=\beta_{1}^{1} f_{i j}^{1}+\beta_{2}^{1} b_{i j}+\beta_{3}^{1} \log d_{i j}+c_{i}+c_{f}
$$

where $f_{i j}^{1}$ is a dummy variable taking a value of 1 when there is at least one direct flight between cities $i$ and $j, b_{i j}$ is a dummy variable taking a value of 1 when there is an international border between cities $i$ and $j, d_{i j}$ is the great circle distance in miles between cities $i$ and $j, c_{i}$ and $c_{f}$ are city fixed effects.

In the second specification, we will consider the effects of the number of direct flights between cities, where we will employ the following regression (where the superscripts represent the specification):

$$
\log \tau_{i j}=\beta_{1}^{2} f_{i j}^{2}+\beta_{2}^{2} b_{i j}+\beta_{3}^{2} \log d_{i j}+c_{i}+c_{f}
$$

where $f_{i j}^{2}$ is the number of direct flights between cities $i$ and $j$, and the remaining notation of variables is the same as in the first specification, above.

In both specifications, the expected sign of $\beta_{1}$ is negative since we expect that having direct flights between any considered city pair is going to reduce trade costs due to the reduced search costs, informational asymmetries, time-to-ship, etc. As consistent with the literature (e.g., Engel and Rogers, 1996), we also expect the effects of international borders 
and distance to be positive (i.e., $\beta_{2}>0$ and $\beta_{3}>0$ ).

Using the estimated coefficients, following the methodology introduced by Parsley and Wei (2001), which is robust to the units of distance measurement used (e.g., miles versus kilometers), the distance equivalent of having direct flights can be measured by the following expression:

$$
F=\overline{d_{i j}}\left(\exp \left(\frac{\beta_{1}}{\beta_{3}}\right)-1\right)
$$

while the distance equivalent of the average international border effect can be measured by the following expression:

$$
B=\overline{d_{i j}}\left(\exp \left(\frac{\beta_{2}}{\beta_{3}}\right)-1\right)
$$

where $\overline{d_{i j}}$ is the average distance between cities, which is about 4,551 miles. In these expressions, we literally determine the corresponding change in distance units to compansate for having direct flights or an international border.

\section{Data and Descriptive Analysis}

Micro price data include observations of 49 goods (22 traded and 27 non-traded) obtained from 433 cities (covering 114 countries) for the years between 2010 and 2014. The complete lists of goods and cities are given in Online Appendix tables, while the coverage of cities are depicted on the world map in Figure 1, where we have multiple cities from many countries. The data have been downloaded from http://www.numbeo.com/ which is the world's largest database of user contributed data about cities. Users of Numbeo can enter the micro prices that they observe either at the good level or by using the price collection sheet provided by the web page. Since the price data are user contributed, Numbeo uses 
alternative methodologies to filter out noise data. First, the user provided data are checked for outliers manually. ${ }^{6}$ Second, one quarter of lowest and highest inputs are discarded as borderline cases. Third, Numbeo uses heuristic technology that discards data which most likely are incorrect statistically. Using the price data, we calculate log trade costs according to Equation 2, where, as indicated in Table 1, the number of city pairs is 90,785, and number of international city pairs are much higher than the number of intranational city pairs.

The data for direct flights have been obtained from Airline Route Mapper for the year of 2013. ${ }^{7}$ The data include information on 63,149 direct flights from around the world where the name of the airlines and airports are also provided. Considering the provided airport codes and names, we determined the exact location of the airports (in terms of their latitudes and longitudes) and the countries in which they are located by using Google Maps.

By using Google Maps, we also calculated the exact location of cities in our price data (in terms of their latitudes and longitudes). Considering these locations, we calculated the great circle distance between them in miles to be used in the regression analysis (see Table 1). Furthermore, in order to determine whether there is a direct flight between any two cities in our price data, we searched for the airports within 50 miles of the city centers by using the airport location data we have. We found that for some cities, there are no airports within 50 miles, while for some others, there are more than one airport; summary statistics are provided in Table 1 where the number of direct flights is 10,677 (out of 90,785). For a given city pair for which prices are compared, we calculated the number of direct flights using the

\footnotetext{
${ }^{6}$ For example, for a particular price in a city, when values contributed are 5, 6, 20, and 4 in a reasonable time span, the value of 20 is discarded as a noise.

${ }^{7}$ The web page is http://arm.64hosts.com/.
} 
direct flight data that we have by considering all available airports within 50 miles. In the empirical investigation, we consider two alternative versions of this information: (i) having at least one direct flight between cities, and (ii) the exact number of direct flights between cities. $^{8}$ For robustness, we also considered alternative measures of proximity to the airport (i.e., airports within 25, 100, and 200 miles of city centers); in Table 1, to save space, we only depict the summary statistics for airports within 100 miles of city centers.

When the maximum price difference across goods is used as the measure of trade costs between cities and airports within 50 miles of city centers are considered to determine direct flights, the corresponding Kernel density estimates are provided in the upper panel of Figure 2, where the city pairs that have a direct flight between each other have fewer trade costs between each other, independent of considering traded or non-traded goods. The results remain the same with a different magnitude when the 80th percentile of price difference across goods is used as the measure of trade costs between cities, as depicted in the lower panel of Figure 2. Therefore, direct flights seems to have a reducing effect on trade costs between cities. Nevertheless, proving this claim requires a formal investigation, of which results we depict next.

\section{Empirical Results}

When the maximum price difference across all goods is used as the measure of trade costs between cities and airports within 50 miles of city centers are considered to determine direct

\footnotetext{
${ }^{8}$ The exact number of direct flights is defined as one flight in any direction between the considered cities. For example, an airline serving between two cities inbound and outbound is considered as two different flights.
} 
flights, the results in Table 2 are obtained for the estimation of Equation 3. As is evident, all considered variables are significant at the $1 \%$ level, and the adjusted R-bar squared values are as high as 0.67 when city fixed effects are included. The main point out of these results is the negative and significant coefficient estimate of the dummy for having at least one direct flight between the considered cities; this result holds for all eight alternative regressions in Table 2 .

We would like to focus on regression version (4) in Table 2, since it includes all the considered variables in Equation 3. The distance-equivalent effects of having at least one direct flight, calculated according to Equation 5, are about -1, 400 miles, while the distanceequivalent effects of borders, calculated according to Equation 6, are about 14,907 miles. ${ }^{9}$ Therefore, the positive effects of having at least one direct flight between any international city pair can compensate for the negative effects of a border by about 10\%, on average across all cities in our sample. When distance elasticity of trade is about one, which is the most commonly estimated coefficient of log distance in gravity studies (e.g., see Disdier and Head, 2008), this result is comparable to the results in Alderighi and Gaggero (2012) who have found that the elasticity of exports to direct flights is about $10 \%$. Since the average distance between the cities in our sample is about 4,551 miles (according to Table 1), we can safely claim that the effect of borders are about triple the effects of distance, while having at least

\footnotetext{
${ }^{9}$ In order to compare this number with the existing literature, consider the following studies that have used alternative data sets and empirical methodologies: Among many others, Engel and Rogers (1996) have estimated the distance equivalent of the U.S.-Canada border about 75,000 miles; Parsley and Wei (2001) have estimated the U.S.-Japan border about 43000 trillion miles; Yilmazkuday (2012) has estimated the average border across states of the U.S. about 3,344 miles.
} 
one direct flight reduces the effects of distance by one third.

When we replicate the results in Table 2 using price data on traded goods only, we obtain the results in Table 3, where the significance and signs of all variables remain the same. When we consider the implied distance-equivalent effects, according regression version (4), having at least one direct flight corresponds to about $-1,000$ miles, while having a border corresponds to about 25,870 miles. Hence, having at least one direct flight between any international city pair reduces the effects of a border by about $4 \%$, on average across all cities in our sample, when price data on traded goods only are considered.

When Equation 4 is estimated to investigate the effects of the number of direct flights on trade costs, the results in Table 2 are replaced by the results in Table 4, where the maximum price difference across all goods is considered as the measure of trade costs, and airports within 50 miles of city centers are considered to determine direct flights. As is evident, again, all considered variables have their expected signs and they are significant at the $1 \%$ level. Having one direct flight reduces trade costs by about 305 miles in distance equivalent terms, on average; hence, an airline serving both an inbound and an outbound flight between two cities reduces trade costs by about $710(=350 \times 2)$ miles in distance equivalent terms. The interesting part of this result is that trade costs are reduced further as the number of direct flights increases. When we replicate the results in Table 4 by using price data on traded goods only, we obtain the results in Table 5, where one direct flight reduces trade costs by about 241 miles in distance equivalent terms, on average.

We considered many alternative estimation strategies for robustness. These include replicating Tables 2-4 by (i) using price data on non-traded goods only, (ii) considering the second maximum of price difference across goods between cities as the measure of trade costs, (iii) 
considering the 80th percentile of price difference across goods between cities as the measure of trade costs, and (iv) considering airports within 100 miles of city centers. All of these investigations resulted in virtually similar results (i.e., direct flights affect trade costs negatively and significantly), which can be found in the Online Appendix of this paper. ${ }^{10}$

\section{Conclusion}

The effects of direct flights on trade costs have been shown to be negative and significant across cities around the world. Having at least one direct flight corresponds to a reduction in trade costs by about 1,400 miles in distance equivalent terms, on average, which is about one third of the average distance between cities. The results also show that one direct flight reduces trade costs by about 305 miles, which is about $7 \%$ of the average distance. Since the average international border is shown to increase trade costs by about 14,907 miles, the positive effects of having at least one direct flight (respectively, having one direct flight) between any two cities can compensate for about 10\% (respectively, 2\%) of the negative effects of an average international border. Therefore, the results, which are supported by many alternative robustness analyses, are in favor of international policies such as Open Skies Agreements that facilitate direct flights and thus reduce trade costs.

The results, for sure, depend on the focus of this paper, which is about the effects of direct flights; alternatively, indirect flights may also be contributing to the reduction of trade costs. However, indirect flights are hard to measure/capture due to the many alternative routes

\footnotetext{
${ }^{10}$ Many other alternative measures can also be investigated by using the to-be-published Matlab codes of this paper.
} 
that one can have; e.g., from New York City, USA to Istanbul, Turkey, there are many alternative airline routes that one can use regarding indirect flights. Such indirect effects, nevertheless, can be investigated by considering the network effects of direct flights across cities, although it is out of the scope of this paper.

\section{References}

[1] Alderighi, M. and Gaggero, A. (2012) "Do non-stop flights boost exports?," mimeo.

[2] Bel, G. and Fageda, X., (2008), "Getting there fast: globalization, intercontinental flights and location of headquarters," Journal of Economic Geography, 8(4): 471-495.

[3] Borraz, F., Cavallo, A., Rigobon, R. and Zipitría, L., (2012) "Distance and Political Boundaries: Estimating Border Effects under Inequality Constraints," mimeo.

[4] Cristea, A.D. (2011) "Buyer-seller relationships in international trade: Evidence from U.S. States' exports and business-class travel," Journal of International Economics, 84: $207-220$.

[5] Disdier, A.C. and Head, K. (2008) "The puzzling persistence of the distance eøect on bilateral trade," The Review of Economics and Statistics 90(1): 37-41.

[6] Eaton, J. and Kortum, S. (2002) " "Technology, Geography, and Trade," Econometrica, $70(5), 1741-1779$.

[7] Engel, C., Rogers, J, (1996), "How wide is the border?" American Economic Review, 86: $1112-1125$. 
[8] Helble, M. (2011) "The movement of patients across borders: Challenges and opportunities for public health," Bulletin of the World Health Organization, 89: 68-72.

[9] Herrick, D.M. (2007), "Medical Tourism: Global Competition in Health Care," National Center for Policy Analysis, Policy Report No. 304.

[10] Hummels, D., (2007) "Transportation Costs and International Trade in the Second Era of Globalization," Journal of Economic Perspectives, 21(3): 131-154.

[11] Hummels, D.L. and Schaur, G., (2013) "Time as a Trade Barrier," American Economic Review, 103(7): 2935-2959.

[12] Ley, D. and Tutchener, J. (2001) "Immigration, Globalisation and House Prices in Canada's Gateway Cities," Housing Studies, 16: 199-223.

[13] Micco, A. and Serebrisky, T. (2006). "Competition Regimes and Air Transport Costs: The effects of open skies agreements," Journal of International Economics, 70: 25-51.

[14] Parsley, D.C.,Wei, S.-J., (2001), "Explaining the border effect: the role of exchange rate variability, shipping costs, and geography," Journal of International Economics, 55(1): $87-105$.

[15] Poole,J.P. (2013) "Business Travel as an Input to International Trade," mimeo.

[16] Simonovska, I. and Waugh, M.E., (2014) "The elasticity of trade: Estimates and evidence," Journal of International Economics, 92(1): 34-50.

[17] Yilmazkuday,H. (2012), "How wide is the border across U.S. states?" Letters in Spatial and Resource Sciences, 5:25-31. 
Figure 1 - Cities in the Micro Price Data

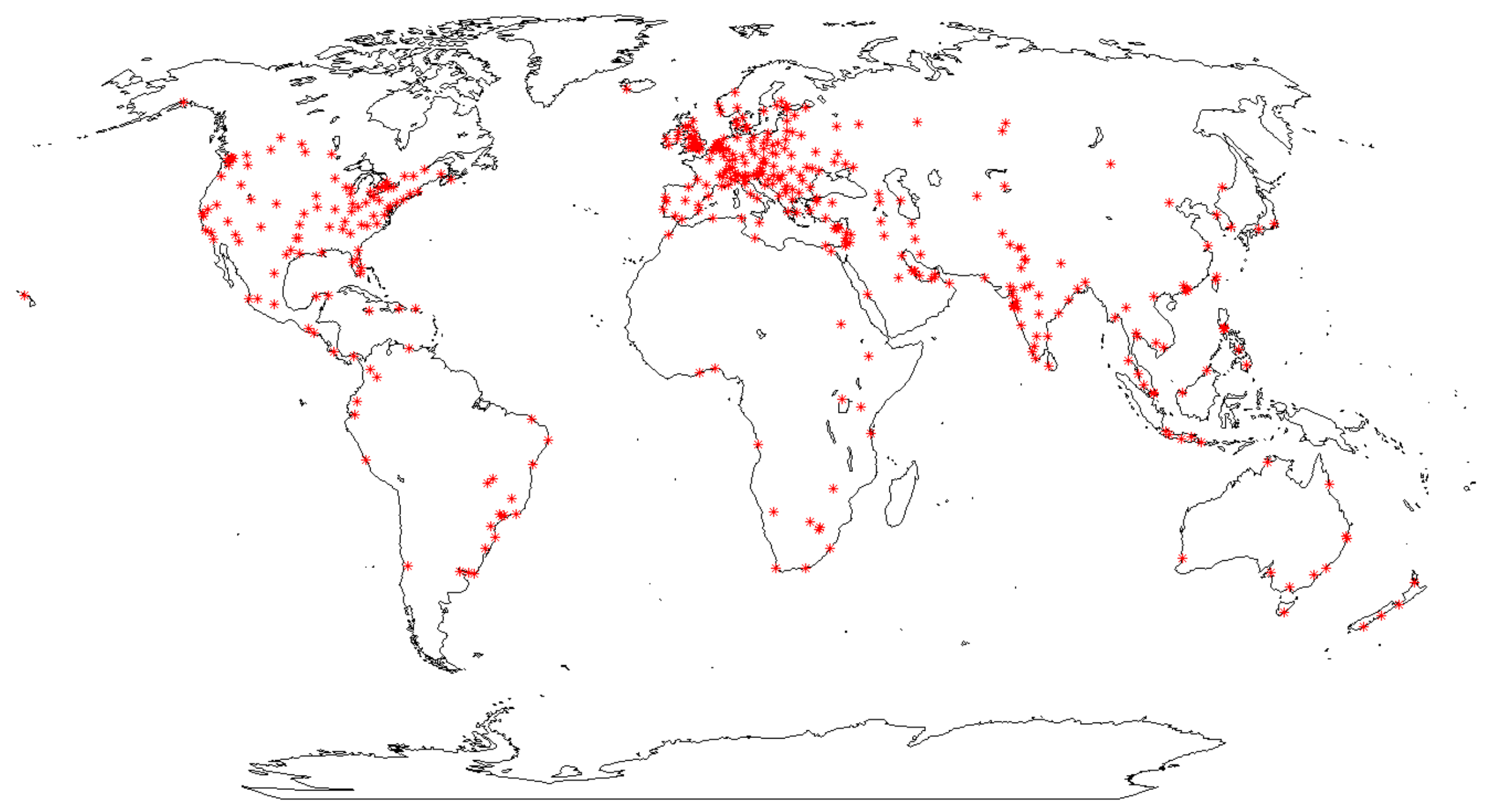

Notes: Each star represents a city in the micro price data. There are 433 cities in the sample. 
Figure 2 - Kernel Density of Price Dispersion across Cities

Maximum Price Difference across All Goods

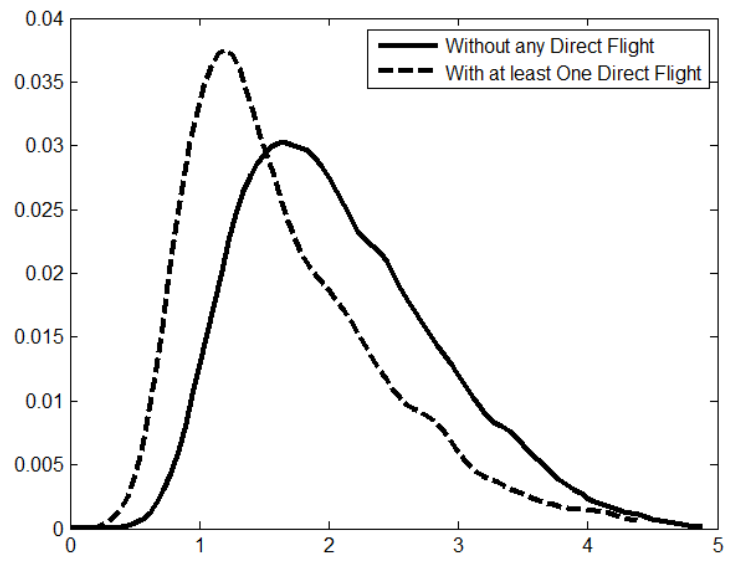

80th Prctile of Price Difference across All Goods

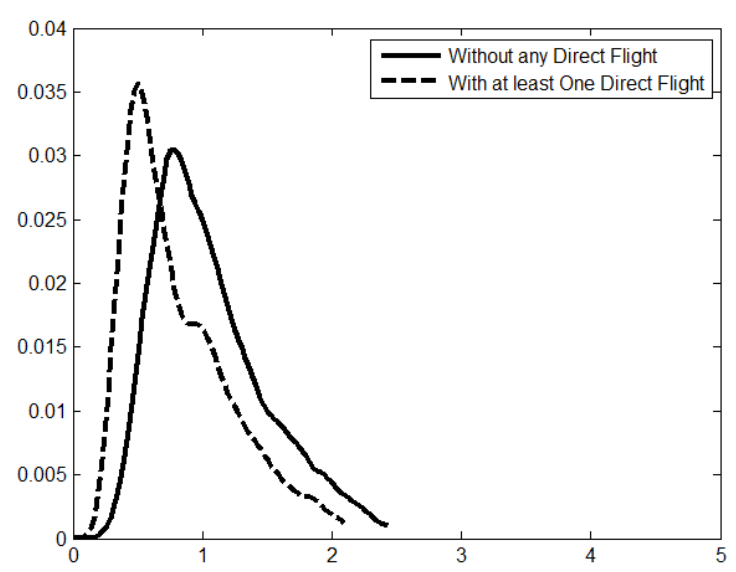

Maximum Price Difference across Traded Goods

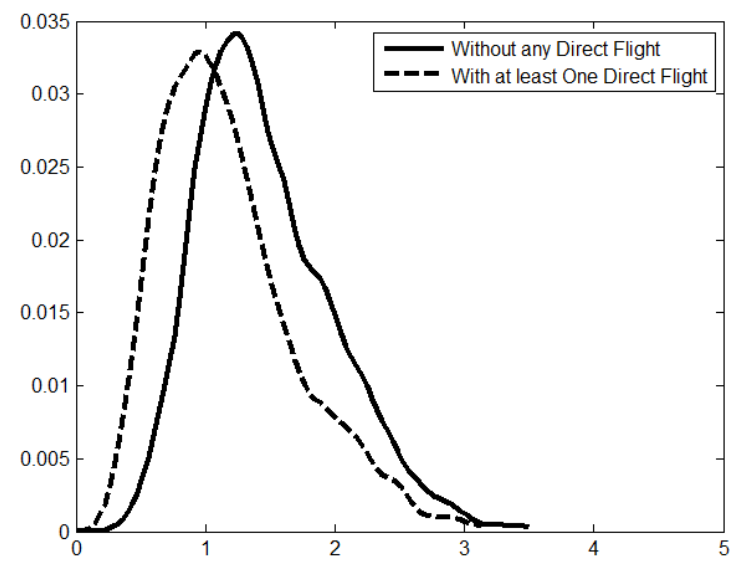

80th Prctile Price of Difference across Traded Goods

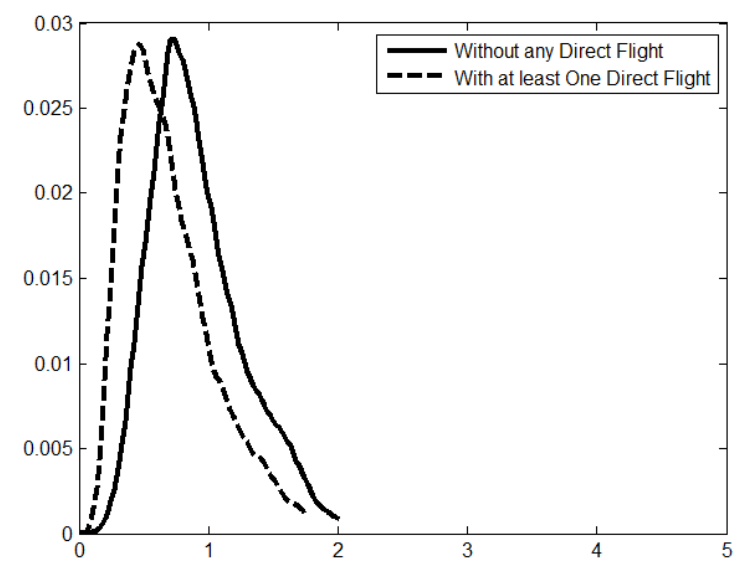

Maximum Price Difference across Non-Traded Goods

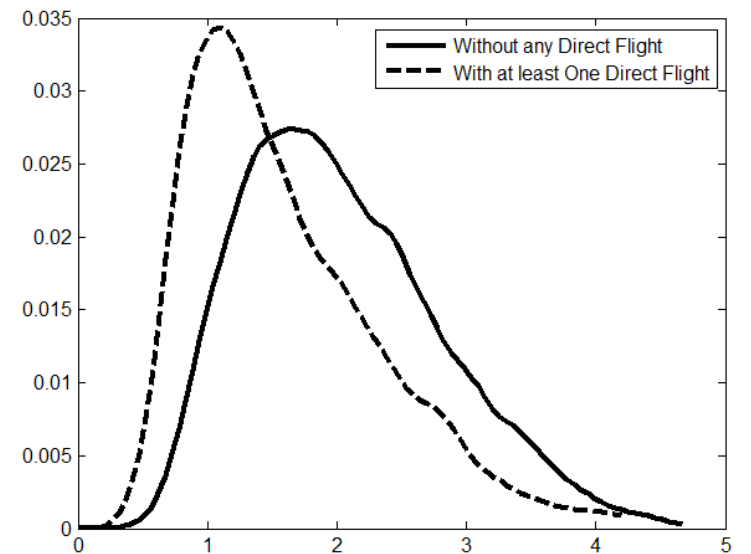

80th Prctile of Price Difference across Non-Traded Goods

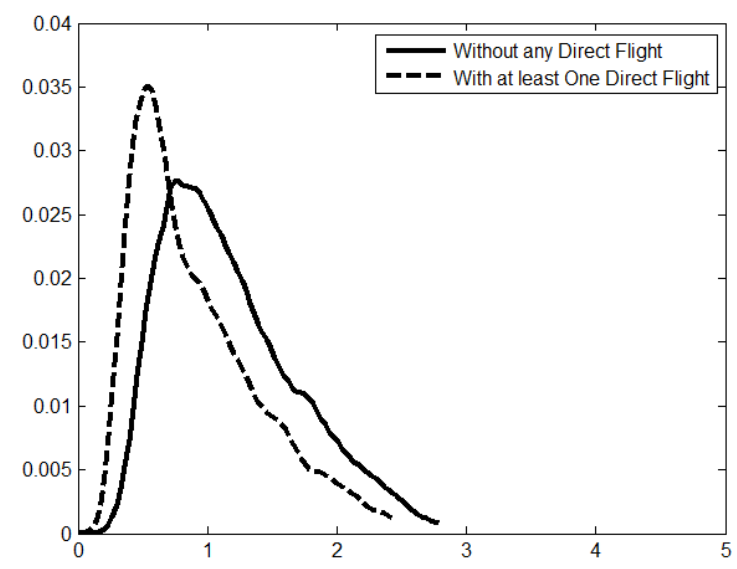

Notes: For any given city pair and each good, the price difference is first calculated as the absolute log price difference. Afterwards, for each city pair, the maximum or the 80th percentile of these price differences are calculated across goods. City pairs with direct flights are defined as the pairs that have at least one direct flight between each other through an airport within 50 miles of the center city. The sample size is 90,785. 
Table 1 - Descriptive Statistics

All City Pairs International City Pairs Intranational City Pairs

Number of City Pairs in Price Data

City Pairs that have at least One Direct Flight through an Airport within 50 Miles

City Pairs that have at least One Direct Flight through an Airport within 100 Miles

Average Distance in Miles
90,785

87,346

3,439

10,677

17,135

14,703

2,432

4,551
980

Source: International city pairs are defined as the pairs that have an international border between them. Intranational city pairs are defined as the pairs that are located in the same country. The availability of the price data has been determined by considering the long-run relative prices between 2010-2014. The availability of the direct flights has been determined according to the data for 2013. 
Table 2 - Effects of Having at Least One Direct Flight on the Maximum Price Difference (across All Goods) through an Airport within 50 Miles

\begin{tabular}{|c|c|c|c|c|c|c|c|c|}
\hline \multirow[t]{2}{*}{ Variables } & \multicolumn{8}{|c|}{ Dependent Variable: Maximum (across All Goods) of Absolute Log Price Difference between Cities } \\
\hline & (1) & $(2)$ & (3) & (4) & (5) & (6) & (7) & (8) \\
\hline $\begin{array}{l}\text { Dummy for Having at Least } \\
\text { One Direct Flight }\end{array}$ & $\begin{array}{c}-0.37 * * * \\
(0.01) \\
{[0.00]}\end{array}$ & $\begin{array}{c}-0.09 * * * \\
(0.01) \\
{[0.00]}\end{array}$ & & $\begin{array}{c}-0.08 * * * \\
(0.01) \\
{[0.00]}\end{array}$ & $\begin{array}{c}-0.43^{* * *} \\
(0.01) \\
{[0.00]}\end{array}$ & $\begin{array}{c}-0.18 * * * \\
(0.01) \\
{[0.00]}\end{array}$ & & $\begin{array}{c}-0.14 * * * \\
(0.01) \\
{[0.00]}\end{array}$ \\
\hline Log Distance & & $\begin{array}{c}0.24 * * * \\
(0.00) \\
{[0.00]}\end{array}$ & $\begin{array}{c}0.21 * * * \\
(0.00) \\
{[0.00]}\end{array}$ & $\begin{array}{c}0.20 * * * \\
(0.00) \\
{[0.00]}\end{array}$ & & $\begin{array}{c}0.22 * * * \\
(0.00) \\
{[0.00]}\end{array}$ & $\begin{array}{c}0.21 * * * \\
(0.00) \\
{[0.00]}\end{array}$ & $\begin{array}{c}0.19 * * * \\
(0.00) \\
{[0.00]}\end{array}$ \\
\hline Border Dummy & & & $\begin{array}{c}0.31 * * * \\
(0.01) \\
{[0.00]}\end{array}$ & $\begin{array}{c}0.30 * * * \\
(0.01) \\
{[0.00]}\end{array}$ & & & $\begin{array}{c}0.51 * * * \\
(0.02) \\
{[0.00]}\end{array}$ & $\begin{array}{c}0.47 * * * \\
(0.02) \\
{[0.00]}\end{array}$ \\
\hline $\begin{array}{l}\text { Distance-Equivalent Effects } \\
\text { of Having at Least One Direct } \\
\text { Flight in Miles }\end{array}$ & & $-1,498$ & & $-1,400$ & & $-2,561$ & & $-2,385$ \\
\hline $\begin{array}{l}\text { Distance-Equivalent Effects } \\
\text { of Borders in Miles }\end{array}$ & & & 14,817 & 14,907 & & & 49,206 & 51,555 \\
\hline City Fixed Effects & YES & YES & YES & YES & NO & NO & NO & NO \\
\hline R-Squared & 0.63 & 0.67 & 0.67 & 0.67 & 0.02 & 0.06 & 0.07 & 0.07 \\
\hline
\end{tabular}


Table 3 - Effects of Having at Least One Direct Flight on the Maximum Price Difference (across Traded Goods) through an Airport within 50 Miles

\begin{tabular}{|c|c|c|c|c|c|c|c|c|}
\hline \multirow[t]{2}{*}{ Variables } & \multicolumn{8}{|c|}{ Dependent Variable: Maximum (across Traded Goods) of Absolute Log Price Difference between Cities } \\
\hline & (1) & $(2)$ & (3) & (4) & (5) & (6) & (7) & (8) \\
\hline $\begin{array}{l}\text { Dummy for Having at Least } \\
\text { One Direct Flight }\end{array}$ & $\begin{array}{c}-0.29 * * * \\
(0.00) \\
{[0.00]}\end{array}$ & $\begin{array}{c}-0.06 * * * \\
(0.00) \\
{[0.00]}\end{array}$ & & $\begin{array}{c}-0.04 * * * \\
(0.01) \\
{[0.00]}\end{array}$ & $\begin{array}{c}-0.29 * * * \\
(0.01) \\
{[0.00]}\end{array}$ & $\begin{array}{c}-0.13^{* * *} \\
(0.01) \\
{[0.00]}\end{array}$ & & $\begin{array}{c}-0.09 * * * \\
(0.01) \\
{[0.00]}\end{array}$ \\
\hline Log Distance & & $\begin{array}{c}0.20 * * * \\
(0.00) \\
{[0.00]}\end{array}$ & $\begin{array}{c}0.17 * * * \\
(0.00) \\
{[0.00]}\end{array}$ & $\begin{array}{c}0.16^{* * *} \\
(0.00) \\
{[0.00]}\end{array}$ & & $\begin{array}{c}0.14 * * * \\
(0.00) \\
{[0.00]}\end{array}$ & $\begin{array}{c}0.12 * * * \\
(0.00) \\
{[0.00]}\end{array}$ & $\begin{array}{c}0.11 * * * \\
(0.00) \\
{[0.00]}\end{array}$ \\
\hline Border Dummy & & & $\begin{array}{c}0.32 * * * \\
(0.01) \\
{[0.00]}\end{array}$ & $\begin{array}{c}0.31 * * * \\
(0.01) \\
{[0.00]}\end{array}$ & & & $\begin{array}{c}0.53 * * * \\
(0.02) \\
{[0.00]}\end{array}$ & $\begin{array}{c}0.51 * * * \\
(0.02) \\
{[0.00]}\end{array}$ \\
\hline $\begin{array}{l}\text { Distance-Equivalent Effects } \\
\text { of Having at Least One Direct } \\
\text { Flight in Miles }\end{array}$ & & $-1,207$ & & $-1,000$ & & $-2,743$ & & $-2,491$ \\
\hline $\begin{array}{l}\text { Distance-Equivalent Effects } \\
\text { of Borders in Miles }\end{array}$ & & & 25,339 & 25,870 & & & 383,948 & 484,132 \\
\hline City Fixed Effects & YES & YES & YES & YES & NO & NO & NO & NO \\
\hline R-Squared & 0.64 & 0.68 & 0.69 & 0.69 & 0.02 & 0.05 & 0.07 & 0.07 \\
\hline
\end{tabular}

Notes: $* * *$, and $* * *$ represent significance at the $10 \%, 5 \%$, and $1 \%$ levels, respectively. Standard errors are in parenthesis and p-values are in brackets. All regressions include a constant that are not shown. 
Table 4 - Effects of the Number of Direct Flights on the Maximum Price Difference (across All Goods) through an Airport within 50 Miles

\begin{tabular}{|c|c|c|c|c|c|c|c|c|}
\hline \multirow[t]{2}{*}{ Variables } & \multicolumn{8}{|c|}{ Dependent Variable: Maximum (across All Goods) of Absolute Log Price Difference between Cities } \\
\hline & (1) & (2) & (3) & (4) & (5) & (6) & (7) & (8) \\
\hline Number of Direct Flights & $\begin{array}{c}-0.04 * * * \\
(0.00) \\
{[0.00]}\end{array}$ & $\begin{array}{c}-0.02 * * * \\
(0.00 \\
{[0.00]}\end{array}$ & & $\begin{array}{c}-0.01 * * * \\
(0.00) \\
{[0.00]}\end{array}$ & $\begin{array}{c}-0.05^{* * *} \\
(0.00) \\
{[0.00]}\end{array}$ & $\begin{array}{c}-0.02 * * * \\
(0.00) \\
{[0.00]}\end{array}$ & & $\begin{array}{c}-0.02 * * * \\
(0.00) \\
{[0.00]}\end{array}$ \\
\hline Log Distance & & $\begin{array}{c}0.23^{* * *} \\
(0.00) \\
{[0.00]}\end{array}$ & $\begin{array}{c}0.21 * * * \\
(0.00) \\
{[0.00]}\end{array}$ & $\begin{array}{c}0.20 * * * \\
(0.00) \\
{[0.00]}\end{array}$ & & $\begin{array}{c}0.22 * * * \\
(0.00) \\
{[0.00]}\end{array}$ & $\begin{array}{c}0.21 * * * \\
(0.00) \\
{[0.00]}\end{array}$ & $\begin{array}{c}0.19 * * * \\
(0.00) \\
{[0.00]}\end{array}$ \\
\hline Border Dummy & & & $\begin{array}{c}0.31 * * * \\
(0.01) \\
{[0.00]}\end{array}$ & $\begin{array}{c}0.29 * * * \\
(0.01) \\
{[0.00]}\end{array}$ & & & $\begin{array}{c}0.51 * * * \\
(0.02) \\
{[0.00]}\end{array}$ & $\begin{array}{c}0.46 * * * \\
(0.02) \\
{[0.00]}\end{array}$ \\
\hline $\begin{array}{l}\text { Distance-Equivalent Effects } \\
\text { of One Direct Flight in Miles }\end{array}$ & & -305 & & -305 & & -476 & & -434 \\
\hline $\begin{array}{l}\text { Distance-Equivalent Effects } \\
\text { of Borders in Miles }\end{array}$ & & & 14,817 & 14,479 & & & 49,206 & 46,791 \\
\hline City Fixed Effects & YES & YES & YES & YES & NO & NO & NO & NO \\
\hline R-Squared & 0.63 & 0.67 & 0.67 & 0.67 & 0.02 & 0.07 & 0.07 & 0.07 \\
\hline
\end{tabular}


Table 5 - Effects of the Number of Direct Flights on the Maximum Price Difference (across Traded Goods) through an Airport within 50 Miles

\begin{tabular}{|c|c|c|c|c|c|c|c|c|}
\hline \multirow[t]{2}{*}{ Variables } & \multicolumn{8}{|c|}{ Dependent Variable: Maximum (across Traded Goods) of Absolute Log Price Difference between Cities } \\
\hline & (1) & $(2)$ & (3) & (4) & (5) & (6) & (7) & (8) \\
\hline Number of Direct Flights & $\begin{array}{c}-0.03 * * * \\
(0.00) \\
{[0.00]}\end{array}$ & $\begin{array}{c}-0.01^{* * *} \\
(0.00 \\
{[0.00]}\end{array}$ & & $\begin{array}{c}-0.01^{* * *} \\
(0.00) \\
{[0.00]}\end{array}$ & $\begin{array}{c}-0.03 * * * \\
(0.00) \\
{[0.00]}\end{array}$ & $\begin{array}{c}-0.02 * * * \\
(0.00) \\
{[0.00]}\end{array}$ & & $\begin{array}{c}-0.01 * * * \\
(0.00) \\
{[0.00]}\end{array}$ \\
\hline Log Distance & & $\begin{array}{c}0.19 * * * \\
(0.00) \\
{[0.00]}\end{array}$ & $\begin{array}{c}0.17 * * * \\
(0.00) \\
{[0.00]}\end{array}$ & $\begin{array}{c}0.16 * * * \\
(0.00) \\
{[0.00]}\end{array}$ & & $\begin{array}{c}0.14^{* * *} \\
(0.00) \\
{[0.00]}\end{array}$ & $\begin{array}{c}0.12 * * * \\
(0.00) \\
{[0.00]}\end{array}$ & $\begin{array}{c}0.11^{* * *} \\
(0.00) \\
{[0.00]}\end{array}$ \\
\hline Border Dummy & & & $\begin{array}{c}0.32 * * * \\
(0.01) \\
{[0.00]}\end{array}$ & $\begin{array}{c}0.30 * * * \\
(0.01) \\
{[0.00]}\end{array}$ & & & $\begin{array}{c}0.53 * * * \\
(0.01) \\
{[0.00]}\end{array}$ & $\begin{array}{c}0.50 * * * \\
(0.01) \\
{[0.00]}\end{array}$ \\
\hline $\begin{array}{l}\text { Distance-Equivalent Effects } \\
\text { of One Direct Flight in Miles }\end{array}$ & & -252 & & -241 & & -561 & & -507 \\
\hline $\begin{array}{l}\text { Distance-Equivalent Effects } \\
\text { of Borders in Miles }\end{array}$ & & & 25,339 & 25,563 & & & 383,948 & 430,132 \\
\hline City Fixed Effects & YES & YES & YES & YES & NO & NO & NO & NO \\
\hline R-Squared & 0.64 & 0.68 & 0.69 & 0.69 & 0.02 & 0.06 & 0.07 & 0.07 \\
\hline
\end{tabular}




\section{Online Appendix (Not For Publication)}

Table A.1 - Goods in the Micro Price Data

\begin{tabular}{|c|c|c|}
\hline Good Code & Goods & Traded Goods \\
\hline 1 & Meal, Inexpensive Restaurant & 0 \\
\hline 2 & Meal for 2, Mid-range Restaurant, Three-course & 0 \\
\hline 3 & Combo Meal at McDonalds or Similar & 0 \\
\hline 4 & Domestic Beer (0.5 liter draught) & 0 \\
\hline 5 & Imported Beer (0.33 liter bottle) & 1 \\
\hline 6 & Coke/Pepsi (0.33 liter bottle) & 1 \\
\hline 7 & Water (0.33 liter bottle) & 1 \\
\hline 8 & Milk (regular), (1 liter) & 1 \\
\hline 9 & Loaf of Fresh White Bread (500g) & 0 \\
\hline 10 & Eggs (12) & 1 \\
\hline 11 & Local Cheese $(1 \mathrm{~kg})$ & 0 \\
\hline 12 & Water (1.5 liter bottle) & 1 \\
\hline 13 & Bottle of Wine (Mid-Range) & 1 \\
\hline 14 & Domestic Beer ( 0.5 liter bottle) & 0 \\
\hline 15 & Imported Beer (0.33 liter bottle) & 1 \\
\hline 16 & Pack of Cigarettes (Marlboro) & 1 \\
\hline 17 & One-way Ticket (Local Transport) & 0 \\
\hline 18 & Chicken Breasts (Boneless, Skinless), (1kg) & 1 \\
\hline 19 & Monthly Pass (Regular Price) & 0 \\
\hline 20 & Gasoline (1 liter) & 1 \\
\hline 21 & Volkswagen Golf 1.490 KW Trendline (Or Equivalent New Car) & 1 \\
\hline 22 & Apartment (1 bedroom) in City Centre & 0 \\
\hline 23 & Apartment ( 1 bedroom) Outside of Centre & 0 \\
\hline 24 & Apartment ( 3 bedrooms) in City Centre & 0 \\
\hline 25 & Apartment (3 bedrooms) Outside of Centre & 0 \\
\hline 26 & Basic (Electricity, Heating, Water, Garbage) for $85 \mathrm{~m} 2$ Apartment & 0 \\
\hline 27 & 1 min. of Prepaid Mobile Tariff Local (No Discounts or Plans) & 0 \\
\hline 28 & Internet (6 Mbps, Unlimited Data, Cable/ADSL) & 0 \\
\hline 29 & Fitness Club, Monthly Fee for 1 Adult & 0 \\
\hline 30 & Tennis Court Rent (1 Hour on Weekend) & 0 \\
\hline 31 & Cinema, International Release, 1 Seat & 0 \\
\hline 32 & 1 Pair of Jeans (Levis 501 Or Similar) & 1 \\
\hline 33 & 1 Summer Dress in a Chain Store (Zara, H\&M, ...) & 1 \\
\hline 34 & 1 Pair of Nike Shoes & 1 \\
\hline 35 & 1 Pair of Men Leather Shoes & 1 \\
\hline 36 & Price per Square Meter to Buy Apartment in City Centre & 0 \\
\hline 37 & Price per Square Meter to Buy Apartment Outside of Centre & 0 \\
\hline 38 & Average Monthly Disposable Salary (After Tax) & 0 \\
\hline 39 & Mortgage Interest Rate in Percentages (\%), Yearly & 0 \\
\hline 40 & Taxi Start (Normal Tariff) & 0 \\
\hline 41 & Taxi $1 \mathrm{~km}$ (Normal Tariff) & 0 \\
\hline 42 & Taxi 1hour Waiting (Normal Tariff) & 0 \\
\hline 43 & Apples $(1 \mathrm{~kg})$ & 1 \\
\hline 44 & Oranges (1kg) & 1 \\
\hline 45 & Potato $(1 \mathrm{~kg})$ & 1 \\
\hline 46 & Lettuce (1 head) & 1 \\
\hline 47 & Cappuccino (regular) & 0 \\
\hline 48 & Rice (white), (1kg) & 1 \\
\hline 49 & Tomato $(1 \mathrm{~kg})$ & 1 \\
\hline
\end{tabular}

Notes: Traded goods take a value of 1 in the last column. 


\section{Online Appendix (Not For Publication)}

Table A.2 - Cities in the Micro Price Data

\begin{tabular}{|c|c|c|c|c|c|c|c|c|}
\hline City & City & City & City & City & City & City & City & City \\
\hline Aachen, Germany & Bhopal, India & Cologne, Germany & Grenoble, France & Kota Kinabalu, Malaysia & Milton Keynes, United Kingdom & Phnom Penh, Cambodia & Sao Jose dos Campos, Brazil & Tunis, Tunisia \\
\hline Aalborg, Denmark & Bhubenswar, India & Colombo, Sri Lanka & Groningen, Netherlands & Kowloon, Hong Kong & Milwaukee, WI, United States & Phoenix, AZ, United States & Sao Paulo, Brazil & Turin, Italy \\
\hline Abbotsford, Canada & Bialystok, Poland & Columbus, OH, United States & Guadalajara, Mexico & Krakow (Cracow), Poland & Minneapolis, MN, United States & Phuket, Thailand & Sarajevo, Bosnia And Herzegovina & Turku, Finland \\
\hline Aberdeen, United Kingdom & Bilbao, Spain & Copenhagen, Denmark & Guangzhou, China & Kuala Lumpur, Malaysia & Minsk, Belarus & Pittsburgh, PA, United States & Saskatoon, Canada & Ulaanbaatar, Mongolia \\
\hline Abu Dhabi, United Arab Emirates & Birmingham, United Kingdom & Cork, Ireland & Guatemala City, Guatemala & Kuching, Malaysia & Mississauga, Canada & Plovdiv, Bulgaria & Seattle, WA, United States & Utrecht, Netherlands \\
\hline Accra, Ghana & Bogota, Colombia & Coventry, United Kingdom & Guildford, United Kingdom & Kuwait City, Kuwait & Monterrey, Mexico & Port Elizabeth, South Africa & Seoul, South Korea & Vadodara, India \\
\hline Ad Dammam, Saudi Arabia & Boise, ID, United States & Cuenca, Ecuador & Gurgaon, India & Lagos, Nigeria & Montevideo, Uruguay & Portland, OR, United States & Sevilla, Spain & Valencia, Spain \\
\hline Addis Ababa, Ethiopia & Bologna, Italy & Curitiba, Brazil & Haifa, Israel & Lahore, Pakistan & Montreal, Canada & Porto Alegre, Brazil & Shanghai, China & Vancouver, Canada \\
\hline Adelaide, Australia & Bordeaux, France & Dallas, TX, United States & Halifax, Canada & Larnaca, Cyprus & Moscow, Russia & Porto, Portugal & Sharjah, United Arab Emirates & Varna, Bulgaria \\
\hline Ahmedabad, India & Boston, MA, United States & Damascus, Syria & Hamburg, Germany & Las Vegas, NV, United States & Mumbai, India & Poznan, Poland & Shenzhen, China & Venice, Italy \\
\hline Akron, OH, United States & Brampton, Canada & Dar Es Salaam, Tanzania & Hamilton, Canada & Lausanne, Switzerland & Munich, Germany & Prague, Czech Republic & Shiraz, Iran & Verona, Italy \\
\hline Albuquerque, NM, United States & Brasilia, Brazil & Darwin, Australia & Hanoi, Vietnam & Leeds, United Kingdom & Muscat, Oman & Pretoria, South Africa & Singapore, Singapore & Vicenza, Italy \\
\hline Alexandria, Egypt & Brasov, Romania & Davao, Philippines & Harare, Zimbabwe & Leicester, United Kingdom & Nagpur, India & Pristina, Serbia & Skopje, Macedonia & Victoria, Canada \\
\hline Algiers, Algeria & Bratislava, Slovakia & Delhi, India & Hartford, CT, United States & Leiden, Netherlands & Nairobi, Kenya & Puerto Vallarta, Mexico & Sliema, Malta & Vienna, Austria \\
\hline Alicante, Spain & Brighton, United Kingdom & Denver, CO, United States & Helsinki, Finland & Lille, France & Nanaimo, BC, Canada & Pune, India & Sofia, Bulgaria & Vilnius, Lithuania \\
\hline Almaty, Kazakhstan & Brisbane, Australia & Detroit, MI, United States & Ho Chi Minh City, Vietnam & Lima, Peru & Naples, Italy & Punta del Este, Uruguay & Split, Croatia & Visakhapatnam, India \\
\hline Amman, Jordan & Bristol, United Kingdom & Dhaka, Bangladesh & Hobart, Australia & Limassol, Cyprus & Nashville, TN, United States & Quebec City, Canada & Spokane, WA, United States & Vladivostok, Russia \\
\hline Amsterdam, Netherlands & Brno, Czech Republic & Dnipropetrovsk, Ukraine & Hong Kong, Hong Kong & Lisbon, Portugal & Nasik, India & Quezon City, Philippines & Stavanger, Norway & Warsaw, Poland \\
\hline Anchorage, AK, United States & Brussels, Belgium & Doha, Qatar & Honolulu, HI, United States & Liverpool, United Kingdom & Navi Mumbai, India & Quito, Ecuador & Stockholm, Sweden & Washington, DC, United States \\
\hline Ankara, Turkey & Bucharest, Romania & Donetsk, Ukraine & Houston, TX, United States & Ljubljana, Slovenia & New Orleans, LA, United States & Raleigh, NC, United States & Strasbourg, France & Waterloo, Canada \\
\hline Antalya, Turkey & Budapest, Hungary & Dresden, Germany & Huntsville, AL, United States & Lodz, Poland & New York, NY, United States & Reading, United Kingdom & Stutgart, Germany & Wellington, New Zealand \\
\hline Antwerp, Belgium & Buenos Aires, Argentina & Dubai, United Arab Emirates & Hyderabad, India & London, Canada & Newcastle Upon Tyne, United Kingdom & Recife, Brazil & Surabaya, Indonesia & West Palm Beach, FL, United States \\
\hline Arhus, Denmark & Buffalo, NY, United States & Dublin, Ireland & Iasi, Romania & London, United Kingdom & Nice, France & Regina, Canada & Surat, India & Wichita, KS, United States \\
\hline Asheville, NC, United States & Bursa, Turkey & Dunedin, New Zealand & Indianapolis, IN, United States & Los Angeles, CA, United States & Nicosia, Cyprus & Reno, NV, United States & Surrey, Canada & Windhoek, Namibia \\
\hline Athens, Greece & Busan, South Korea & Durban, South Africa & Indore, India & Louisville, KY, United States & Nis, Serbia & Reykjavik, Iceland & Sydney, Australia & Windsor, Canada \\
\hline Atlanta, GA, United States & Bydgoszzz, Poland & Dusseldorf, Germany & Irbil, Iraq & Luanda, Angola & Nizhniy Novgorod, Russia & Richmond, VA, United States & Szczecin, Poland & Winnipeg, Canada \\
\hline Auckland, New Zealand & Cairns, Australia & Edinburgh, United Kingdom & Islamabad, Pakistan & Lublin, Poland & Noida, India & Riga, Latvia & Taichung, Taiwan & Wroclaw, Poland \\
\hline Austin, TX, United States & Cairo, Egypt & Edmonton, Canada & Istanbul, Turkey & Ludhiana, India & Nottingham, United Kingdom & Rijeka, Croatia & Taipei, Taiwan & Yangon, Myanmar \\
\hline Baghdad, Iraq & Calgary, Canada & Eindhoven, Netherlands & Izmir, Turkey & Lugano, Switzerland & Novi Sad, Serbia & Rio De Janeiro, Brazil & Tallinn, Estonia & Yekaterinburg, Russia \\
\hline Bahrain, Bahrain & Cambridge, United Kingdom & Esfahan, Iran & Jacksonville, FL, United States & Luxembourg, Luxembourg & Novosibirsk, Russia & Riyadh, Saudi Arabia & Tampa, FL, United States & Yerevan, Armenia \\
\hline Baku, Azerbaijan & Campinas, Brazil & Espoo, Finland & Jaipur, India & Lviv, Ukraine & Nuremberg, Germany & Roanoke, VA, United States & Tampere, Finland & Yogyakarta, Indonesia \\
\hline Bali, Indonesia & Canberra, Australia & Florence, Italy & Jakarta, Indonesia & Lyon, France & Odesa, Ukraine & Rochester, NY, United States & Tartu, Estonia & Zagreb, Croatia \\
\hline Baltimore, MD, United States & Cancun, Mexico & Florianopolis, Brazil & Jeddah (Jiddah), Saudi Arabia & Масао, Масао & Oklahoma City, OK, United States & Rome, Italy & Tashkent, Uzbekistan & Zurich, Switzerland \\
\hline Bandung, Indonesia & Cape Town, South Africa & Fort Lauderdale, FL, United States & Jerusalem, Israel & Madison, WI, United States & Omaha, NE, United States & Rostov-na-donu, Russia & Tbilisi, Georgia & \\
\hline Bangalore, India & Caracas, Venezuela & Fort Worth, TX, United States & Johannesburg, South Africa & Madrid, Spain & Orlando, FL, United States & Rotterdam, Netherlands & Tehran, Iran & \\
\hline Bangkok, Thailand & Cardiff, United Kingdom & Fortaleza, Brazil & Johor Baharu, Malaysia & Makati, Philippines & Osaka, Japan & Sacramento, CA, United States & Tel Aviv-Yafo, Israel & \\
\hline Banja Luka, Bosnia And Herzegovina & Casablanca, Morocco & Frankfurt, Germany & Kampala, Uganda & Malaga, Spain & Osijek, Croatia & Saint Louis, MO, United States & Thane, India & \\
\hline Barcelona, Spain & Cebu, Philippines & Fredericton, Canada & Kansas City, MO, United States & Malmo, Sweden & Oslo, Norway & Saint Petersburg, Russia & The Hague, Netherlands & \\
\hline Barrie, Canada & Chandigarh, India & Gaborone, Botswana & Karachi, Pakistan & Manama, Bahrain & Ottawa, Canada & Salt Lake City, UT, United States & Thessaloniki, Greece & \\
\hline Basel, Switzerland & Charlotte, NC, United States & Galway, Ireland & Kathmandu, Nepal & Manchester, United Kingdom & Oxford, United Kingdom & Salvador, Brazil & Thiruvananthapuram, India & \\
\hline Beersheba, Israel & Chennai, India & Gdansk, Poland & Katowice, Poland & Manila, Philippines & Padova, Italy & San Antonio, TX, United States & Timisoara, Romania & \\
\hline Beijing, China & Chiang Mai, Thailand & Geneva, Switzerland & Kaunas, Lithuania & Maribor, Slovenia & Panama City, Panama & San Diego, CA, United States & Tirana, Albania & \\
\hline Beirut, Lebanon & Chicago, IL, United States & Genoa, Italy & Kelowna, Canada & Marseille, France & Paphos, Cyprus & San Francisco, CA, United States & Tokyo, Japan & \\
\hline Belfast, United Kingdom & Chisinau, Moldova & Gent, Belgium & Kharkiv, Ukraine & Medellin, Colombia & Paris, France & San Jose, CA, United States & Tomsk, Russia & \\
\hline Belgrade, Serbia & Christchurch, New Zealand & Glasgow, United Kingdom & Khartoum, Sudan & Melbourne, Australia & Patras, Greece & San Jose, Costa Rica & Toronto, Canada & \\
\hline Belo Horizonte, Brazil & Cincinnati, OH, United States & Goa, India & Kiev, Ukraine & Memphis, TN, United States & Pattaya, Thailand & San Juan, Puerto Rico & Toulouse, France & \\
\hline Bergamo, Italy & Cleveland, ОH, United States & Goiania, Brazil & Kingston, Jamaica & Merida, Mexico & Penang, Malaysia & San Salvador, El Salvador & Trieste, Italy & \\
\hline Bergen, Norway & Cluj-napoca, Romania & Gold Coast, Australia & Kitchener, Canada & Mexico City, Mexico & Perth, Australia & Santa Barbara, CA, United States & Tripoli, Libya & \\
\hline Berlin, Germany & Coimbatore, India & Gothenburg, Sweden & Kochi, India & Miami, FL, United States & Petaling Jaya, Malaysia & Santiago, Chile & Trondheim, Norway & \\
\hline Bern, Switzerland & Coimbra, Portugal & Graz, Austria & Kolkata, India & Milan, Italy & Philadelphia, PA, United States & Santo Domingo, Dominican Republic & Tucson, AZ, United States & \\
\hline
\end{tabular}




\section{Online Appendix (Not For Publication)}

Table A.3-Effects of Having at Least One Direct Flight on the Maximum Price Difference (across NonTraded Goods) through an Airport within 50 Miles

\begin{tabular}{|c|c|c|c|c|c|c|c|c|}
\hline \multirow[t]{2}{*}{ Variables } & \multicolumn{8}{|c|}{ Dependent Variable: Maximum (across Non-Traded Goods) of Absolute Log Price Difference between Cities } \\
\hline & (1) & (2) & (3) & (4) & (5) & (6) & (7) & (8) \\
\hline $\begin{array}{l}\text { Dummy for Having at Least } \\
\text { One Direct Flight }\end{array}$ & $\begin{array}{c}-0.37 * * * \\
(0.01) \\
{[0.00]}\end{array}$ & $\begin{array}{c}-0.09 * * * \\
(0.01) \\
{[0.00]}\end{array}$ & & $\begin{array}{c}-0.07 * * * \\
(0.01) \\
{[0.00]}\end{array}$ & $\begin{array}{c}-0.43 * * * \\
(0.01) \\
{[0.00]}\end{array}$ & $\begin{array}{c}-0.16^{* * *} \\
(0.01) \\
{[0.00]}\end{array}$ & & $\begin{array}{c}-0.13^{* * *} \\
(0.01) \\
{[0.00]}\end{array}$ \\
\hline Log Distance & & $\begin{array}{c}0.24 * * * \\
(0.00) \\
{[0.00]}\end{array}$ & $\begin{array}{c}0.21 * * * \\
(0.00) \\
{[0.00]}\end{array}$ & $\begin{array}{c}0.20 * * * \\
(0.00) \\
{[0.00]}\end{array}$ & & $\begin{array}{c}0.23 * * * \\
(0.00) \\
{[0.00]}\end{array}$ & $\begin{array}{c}0.22 * * * \\
(0.00) \\
{[0.00]}\end{array}$ & $\begin{array}{c}0.21^{* * *} \\
(0.00) \\
{[0.00]}\end{array}$ \\
\hline Border Dummy & & & $\begin{array}{c}0.31 * * * \\
(0.01) \\
{[0.00]}\end{array}$ & $\begin{array}{c}0.30 * * * \\
(0.01) \\
{[0.00]}\end{array}$ & & & $\begin{array}{c}0.46 * * * \\
(0.02) \\
{[0.00]}\end{array}$ & $\begin{array}{c}0.43 * * * \\
(0.02) \\
{[0.00]}\end{array}$ \\
\hline $\begin{array}{l}\text { Distance-Equivalent Effects } \\
\text { of Having at Least One Direct } \\
\text { Flight in Miles }\end{array}$ & & $-1,404$ & & $-1,286$ & & $-2,280$ & & $-2,076$ \\
\hline $\begin{array}{l}\text { Distance-Equivalent Effects } \\
\text { of Borders in Miles }\end{array}$ & & & 15,112 & 15,208 & & & 30,968 & 31,164 \\
\hline City Fixed Effects & YES & YES & YES & YES & NO & NO & NO & NO \\
\hline R-Squared & 0.57 & 0.61 & 0.61 & 0.61 & 0.02 & 0.08 & 0.08 & 0.09 \\
\hline
\end{tabular}




\section{Online Appendix (Not For Publication)}

Table A.4- Effects of the Number of Direct Flights on the Maximum Price Difference (across NonTraded Goods) through an Airport within 50 Miles

\begin{tabular}{|c|c|c|c|c|c|c|c|c|}
\hline \multirow[t]{2}{*}{ Variables } & \multicolumn{8}{|c|}{ Dependent Variable: Maximum (across Non-Traded Goods) of Absolute Log Price Difference between Cities } \\
\hline & $(1)$ & $(2)$ & (3) & $(4)$ & (5) & (6) & $(7)$ & (8) \\
\hline Number of Direct Flights & $\begin{array}{c}-0.04^{* * *} \\
(0.00) \\
{[0.00]}\end{array}$ & $\begin{array}{c}-0.02 * * * \\
(0.00 \\
{[0.00]}\end{array}$ & & $\begin{array}{c}-0.01 * * * \\
(0.00) \\
{[0.00]}\end{array}$ & $\begin{array}{c}-0.05 * * * \\
(0.00) \\
{[0.00]}\end{array}$ & $\begin{array}{c}-0.02 * * * \\
(0.00) \\
{[0.00]}\end{array}$ & & $\begin{array}{c}-0.02 * * * \\
(0.00) \\
{[0.00]}\end{array}$ \\
\hline Log Distance & & $\begin{array}{c}0.23 * * * \\
(0.00) \\
{[0.00]}\end{array}$ & $\begin{array}{c}0.21 * * * \\
(0.00) \\
{[0.00]}\end{array}$ & $\begin{array}{c}0.20 * * * \\
(0.00) \\
{[0.00]}\end{array}$ & & $\begin{array}{c}0.23 * * * \\
(0.00) \\
{[0.00]}\end{array}$ & $\begin{array}{c}0.22 * * * \\
(0.00) \\
{[0.00]}\end{array}$ & $\begin{array}{c}0.21 * * * \\
(0.00) \\
{[0.00]}\end{array}$ \\
\hline Border Dummy & & & $\begin{array}{c}0.31 * * * \\
(0.01) \\
{[0.00]}\end{array}$ & $\begin{array}{c}0.29 * * * \\
(0.01) \\
{[0.00]}\end{array}$ & & & $\begin{array}{c}0.46 * * * \\
(0.02) \\
{[0.00]}\end{array}$ & $\begin{array}{c}0.41^{* * *} \\
(0.02) \\
{[0.00]}\end{array}$ \\
\hline $\begin{array}{l}\text { Distance-Equivalent Effects } \\
\text { of One Direct Flight in Miles }\end{array}$ & & -317 & & -319 & & -429 & & -388 \\
\hline $\begin{array}{l}\text { Distance-Equivalent Effects } \\
\text { of Borders in Miles }\end{array}$ & & & 15,112 & 14,771 & & & 30,968 & 28,660 \\
\hline City Fixed Effects & YES & YES & YES & YES & NO & NO & NO & NO \\
\hline R-Squared & 0.57 & 0.61 & 0.61 & 0.61 & 0.02 & 0.08 & 0.08 & 0.09 \\
\hline
\end{tabular}

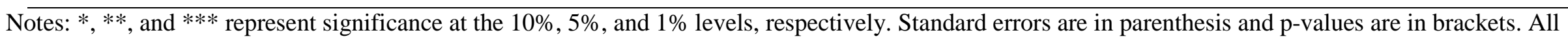
regressions include a constant that are not shown. 


\section{Online Appendix (Not For Publication)}

Table A.5 - Effects of Having at Least One Direct Flight on the Second Maximum Price Difference (across All Goods) through an Airport within 50 Miles

\begin{tabular}{|c|c|c|c|c|c|c|c|c|}
\hline \multirow[t]{2}{*}{ Variables } & \multicolumn{8}{|c|}{ Dependent Variable: Second Maximum (across All Goods) of Absolute Log Price Difference between Cities } \\
\hline & (1) & (2) & (3) & (4) & (5) & (6) & (7) & (8) \\
\hline $\begin{array}{l}\text { Dummy for Having at Least } \\
\text { One Direct Flight }\end{array}$ & $\begin{array}{c}-0.36 * * * \\
(0.01) \\
{[0.00]}\end{array}$ & $\begin{array}{c}-0.09 * * * \\
(0.01) \\
{[0.00]}\end{array}$ & & $\begin{array}{c}-0.07 * * * \\
(0.01) \\
{[0.00]}\end{array}$ & $\begin{array}{c}-0.40 * * * \\
(0.01) \\
{[0.00]}\end{array}$ & $\begin{array}{c}-0.16^{* * *} \\
(0.01) \\
{[0.00]}\end{array}$ & & $\begin{array}{c}-0.12^{* * *} \\
(0.01) \\
{[0.00]}\end{array}$ \\
\hline Log Distance & & $\begin{array}{c}0.23 * * * \\
(0.00) \\
{[0.00]}\end{array}$ & $\begin{array}{c}0.20 * * * \\
(0.00) \\
{[0.00]}\end{array}$ & $\begin{array}{c}0.19 * * * \\
(0.00) \\
{[0.00]}\end{array}$ & & $\begin{array}{c}0.20 * * * \\
(0.00) \\
{[0.00]}\end{array}$ & $\begin{array}{c}0.19 * * * \\
(0.00) \\
{[0.00]}\end{array}$ & $\begin{array}{c}0.17^{* * *} \\
(0.00) \\
{[0.00]}\end{array}$ \\
\hline Border Dummy & & & $\begin{array}{c}0.33 * * * \\
(0.01) \\
{[0.00]}\end{array}$ & $\begin{array}{c}0.32 * * * \\
(0.01) \\
{[0.00]}\end{array}$ & & & $\begin{array}{c}0.51 * * * \\
(0.01) \\
{[0.00]}\end{array}$ & $\begin{array}{c}0.48 * * * \\
(0.01) \\
{[0.00]}\end{array}$ \\
\hline $\begin{array}{l}\text { Distance-Equivalent Effects } \\
\text { of Having at Least One Direct } \\
\text { Flight in Miles }\end{array}$ & & $-1,505$ & & $-1,395$ & & $-2,488$ & & $-2,273$ \\
\hline $\begin{array}{l}\text { Distance-Equivalent Effects } \\
\text { of Borders in Miles }\end{array}$ & & & 18,672 & 18,989 & & & 63,513 & 67,651 \\
\hline City Fixed Effects & YES & YES & YES & YES & NO & NO & NO & NO \\
\hline R-Squared & 0.56 & 0.60 & 0.61 & 0.61 & 0.03 & 0.09 & 0.10 & 0.10 \\
\hline
\end{tabular}




\section{Online Appendix (Not For Publication)}

Table A.6 - Effects of the Number of Direct Flights on the Second Maximum Price Difference (across All Goods) through an Airport within 50 Miles

\begin{tabular}{|c|c|c|c|c|c|c|c|c|}
\hline \multirow[t]{2}{*}{ Variables } & \multicolumn{8}{|c|}{ Dependent Variable: Second Maximum (across All Goods) of Absolute Log Price Difference between Cities } \\
\hline & $(1)$ & $(2)$ & (3) & (4) & (5) & (6) & (7) & (8) \\
\hline Number of Direct Flights & $\begin{array}{c}-0.04 * * * \\
(0.00) \\
{[0.00]}\end{array}$ & $\begin{array}{c}-0.02 * * * \\
(0.00 \\
{[0.00]}\end{array}$ & & $\begin{array}{c}-0.01 * * * \\
(0.00) \\
{[0.00]}\end{array}$ & $\begin{array}{c}-0.05 * * * \\
(0.00) \\
{[0.00]}\end{array}$ & $\begin{array}{c}-0.02 * * * \\
(0.00) \\
{[0.00]}\end{array}$ & & $\begin{array}{c}-0.02 * * * \\
(0.00) \\
{[0.00]}\end{array}$ \\
\hline Log Distance & & $\begin{array}{c}0.22 * * * \\
(0.00) \\
{[0.00]}\end{array}$ & $\begin{array}{c}0.20 * * * \\
(0.00) \\
{[0.00]}\end{array}$ & $\begin{array}{c}0.19 * * * \\
(0.00) \\
{[0.00]}\end{array}$ & & $\begin{array}{c}0.21 * * * \\
(0.00) \\
{[0.00]}\end{array}$ & $\begin{array}{c}0.19 * * * \\
(0.00) \\
{[0.00]}\end{array}$ & $\begin{array}{c}0.18^{* * *} \\
(0.00) \\
{[0.00]}\end{array}$ \\
\hline Border Dummy & & & $\begin{array}{c}0.33^{* * *} \\
(0.01) \\
{[0.00]}\end{array}$ & $\begin{array}{c}0.31 * * * \\
(0.01) \\
{[0.00]}\end{array}$ & & & $\begin{array}{c}0.51 * * * \\
(0.01) \\
{[0.00]}\end{array}$ & $\begin{array}{c}0.47 * * * \\
(0.01) \\
{[0.00]}\end{array}$ \\
\hline $\begin{array}{l}\text { Distance-Equivalent Effects } \\
\text { of One Direct Flight in Miles }\end{array}$ & & -315 & & -316 & & -466 & & -418 \\
\hline $\begin{array}{l}\text { Distance-Equivalent Effects } \\
\text { of Borders in Miles }\end{array}$ & & & 18,672 & 18,521 & & & 63,513 & 61,633 \\
\hline City Fixed Effects & YES & YES & YES & YES & NO & NO & NO & NO \\
\hline R-Squared & 0.56 & 0.60 & 0.61 & 0.61 & 0.03 & 0.09 & 0.10 & 0.10 \\
\hline
\end{tabular}

Notes: $*{ }^{* *}$, and ${ }^{* * *}$ represent significance at the $10 \%, 5 \%$, and $1 \%$ levels, respectively. Standard errors are in parenthesis and p-values are in brackets. All regressions include a constant that are not shown. 


\section{Online Appendix (Not For Publication)}

Table A.7 - Effects of Having at Least One Direct Flight on the 80th Percentile of Price Difference (across All Goods) through an Airport within 50 Miles

\begin{tabular}{|c|c|c|c|c|c|c|c|c|}
\hline \multirow[t]{2}{*}{ Variables } & \multicolumn{8}{|c|}{ Dependent Variable: 80th Percentile (across All Goods) of Absolute Log Price Difference between Cities } \\
\hline & $(1)$ & $(2)$ & (3) & (4) & (5) & (6) & (7) & (8) \\
\hline $\begin{array}{l}\text { Dummy for Having at Least } \\
\text { One Direct Flight }\end{array}$ & $\begin{array}{c}-0.25 * * * \\
(0.00) \\
{[0.00]}\end{array}$ & $\begin{array}{c}-0.04 * * * \\
(0.00) \\
{[0.00]}\end{array}$ & & $\begin{array}{c}-0.07 * * * \\
(0.00) \\
{[0.00]}\end{array}$ & $\begin{array}{c}-0.25^{* * *} \\
(0.00) \\
{[0.00]}\end{array}$ & $\begin{array}{c}-0.10 * * * \\
(0.00) \\
{[0.00]}\end{array}$ & & $\begin{array}{c}-0.06 * * * \\
(0.00) \\
{[0.00]}\end{array}$ \\
\hline Log Distance & & $\begin{array}{c}0.17^{* * *} \\
(0.00) \\
{[0.00]}\end{array}$ & $\begin{array}{c}0.15^{* * *} \\
(0.00) \\
{[0.00]}\end{array}$ & $\begin{array}{c}0.14 * * * \\
(0.00) \\
{[0.00]}\end{array}$ & & $\begin{array}{c}0.13 * * * \\
(0.00) \\
{[0.00]}\end{array}$ & $\begin{array}{c}0.11 * * * \\
(0.00) \\
{[0.00]}\end{array}$ & $\begin{array}{c}0.11^{* * *} \\
(0.00) \\
{[0.00]}\end{array}$ \\
\hline Border Dummy & & & $\begin{array}{c}0.29 * * * \\
(0.01) \\
{[0.00]}\end{array}$ & $\begin{array}{c}0.29 * * * \\
(0.01) \\
{[0.00]}\end{array}$ & & & $\begin{array}{c}0.43 * * * \\
(0.01) \\
{[0.00]}\end{array}$ & $\begin{array}{c}0.42^{* * *} \\
(0.01) \\
{[0.00]}\end{array}$ \\
\hline $\begin{array}{l}\text { Distance-Equivalent Effects } \\
\text { of Having at Least One Direct } \\
\text { Flight in Miles }\end{array}$ & & $-1,001$ & & -714 & & $-2,387$ & & $-2,024$ \\
\hline $\begin{array}{l}\text { Distance-Equivalent Effects } \\
\text { of Borders in Miles }\end{array}$ & & & 29,621 & 30,144 & & & 211,128 & 241,002 \\
\hline City Fixed Effects & YES & YES & YES & YES & NO & NO & NO & NO \\
\hline R-Squared & 0.43 & 0.50 & 0.51 & 0.51 & 0.03 & 0.09 & 0.12 & 0.12 \\
\hline
\end{tabular}

Notes: *, **, and *** represent significance at the 10\%, 5\%, and 1\% levels, respectively. Standard errors are in parenthesis and p-values are in brackets. All regressions include a constant that are not shown. 


\section{Online Appendix (Not For Publication)}

Table A.8 - Effects of the Number of Direct Flights on the 80th Percentile of Price Difference (across All Goods) through an Airport within 50 Miles

\begin{tabular}{|c|c|c|c|c|c|c|c|c|}
\hline \multirow[t]{2}{*}{ Variables } & \multicolumn{8}{|c|}{ Dependent Variable: 80th Percentile (across All Goods) of Absolute Log Price Difference between Cities } \\
\hline & $(1)$ & $(2)$ & (3) & $(4)$ & (5) & (6) & $(7)$ & (8) \\
\hline Number of Direct Flights & $\begin{array}{c}-0.03 * * * \\
(0.00) \\
{[0.00]}\end{array}$ & $\begin{array}{c}-0.01 * * * \\
(0.00 \\
{[0.00]}\end{array}$ & & $\begin{array}{c}-0.01 * * * \\
(0.00) \\
{[0.00]}\end{array}$ & $\begin{array}{c}-0.03 * * * \\
(0.00) \\
{[0.00]}\end{array}$ & $\begin{array}{c}-0.01 * * * \\
(0.00) \\
{[0.00]}\end{array}$ & & $\begin{array}{c}-0.01 * * * \\
(0.00) \\
{[0.00]}\end{array}$ \\
\hline Log Distance & & $\begin{array}{c}0.17^{* * *} \\
(0.00) \\
{[0.00]}\end{array}$ & $\begin{array}{c}0.15^{* * *} \\
(0.00) \\
{[0.00]}\end{array}$ & $\begin{array}{c}0.14^{* * *} \\
(0.00) \\
{[0.00]}\end{array}$ & & $\begin{array}{c}0.13 * * * \\
(0.00) \\
{[0.00]}\end{array}$ & $\begin{array}{c}0.11 * * * \\
(0.00) \\
{[0.00]}\end{array}$ & $\begin{array}{c}0.11^{* * *} \\
(0.00) \\
{[0.00]}\end{array}$ \\
\hline Border Dummy & & & $\begin{array}{c}0.29 * * * \\
(0.01) \\
{[0.00]}\end{array}$ & $\begin{array}{c}0.28 * * * \\
(0.01) \\
{[0.00]}\end{array}$ & & & $\begin{array}{c}0.43^{* * *} \\
(0.01) \\
{[0.00]}\end{array}$ & $\begin{array}{c}0.41 * * * \\
(0.01) \\
{[0.00]}\end{array}$ \\
\hline $\begin{array}{l}\text { Distance-Equivalent Effects } \\
\text { of One Direct Flight in Miles }\end{array}$ & & -290 & & -287 & & -484 & & -418 \\
\hline $\begin{array}{l}\text { Distance-Equivalent Effects } \\
\text { of Borders in Miles }\end{array}$ & & & 29,621 & 30,198 & & & 211,128 & 222,461 \\
\hline City Fixed Effects & YES & YES & YES & YES & NO & NO & NO & NO \\
\hline R-Squared & 0.43 & 0.50 & 0.51 & 0.51 & 0.03 & 0.10 & 0.12 & 0.12 \\
\hline
\end{tabular}

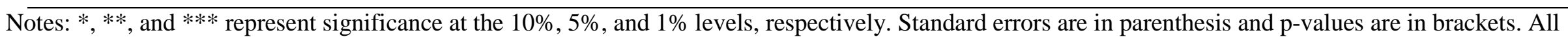
regressions include a constant that are not shown. 


\section{Online Appendix (Not For Publication)}

Table A.9 - Effects of Having at Least One Direct Flight on the Maximum Price Difference (across All Goods) through an Airport within 100 Miles

\begin{tabular}{|c|c|c|c|c|c|c|c|c|}
\hline \multirow[t]{2}{*}{ Variables } & \multicolumn{8}{|c|}{ Dependent Variable: Maximum (across All Goods) of Absolute Log Price Difference between Cities } \\
\hline & $(1)$ & $(2)$ & (3) & (4) & (5) & (6) & (7) & (8) \\
\hline $\begin{array}{l}\text { Dummy for Having at Least } \\
\text { One Direct Flight }\end{array}$ & $\begin{array}{c}-0.36 * * * \\
(0.01) \\
{[0.00]}\end{array}$ & $\begin{array}{c}-0.08 * * * \\
(0.01) \\
{[0.00]}\end{array}$ & & $\begin{array}{c}-0.07 * * * \\
(0.01) \\
{[0.00]}\end{array}$ & $\begin{array}{c}-0.42 * * * \\
(0.01) \\
{[0.00]}\end{array}$ & $\begin{array}{c}-0.18 * * * \\
(0.01) \\
{[0.00]}\end{array}$ & & $\begin{array}{c}-0.15^{* * *} \\
(0.01) \\
{[0.00]}\end{array}$ \\
\hline Log Distance & & $\begin{array}{c}0.23 * * * \\
(0.00) \\
{[0.00]}\end{array}$ & $\begin{array}{c}0.21 * * * \\
(0.00) \\
{[0.00]}\end{array}$ & $\begin{array}{c}0.20 * * * \\
(0.00) \\
{[0.00]}\end{array}$ & & $\begin{array}{c}0.21^{* * *} \\
(0.00) \\
{[0.00]}\end{array}$ & $\begin{array}{c}0.21 * * * \\
(0.00) \\
{[0.00]}\end{array}$ & $\begin{array}{c}0.18 * * * \\
(0.00) \\
{[0.00]}\end{array}$ \\
\hline Border Dummy & & & $\begin{array}{c}0.31^{* * *} \\
(0.01) \\
{[0.00]}\end{array}$ & $\begin{array}{c}0.30 * * * \\
(0.01) \\
{[0.00]}\end{array}$ & & & $\begin{array}{c}0.51 * * * \\
(0.02) \\
{[0.00]}\end{array}$ & $\begin{array}{c}0.48 * * * \\
(0.02) \\
{[0.00]}\end{array}$ \\
\hline $\begin{array}{l}\text { Distance-Equivalent Effects } \\
\text { of Having at Least One Direct } \\
\text { Flight in Miles }\end{array}$ & & $-1,318$ & & $-1,258$ & & $-2,642$ & & $-2,623$ \\
\hline $\begin{array}{l}\text { Distance-Equivalent Effects } \\
\text { of Borders in Miles }\end{array}$ & & & 14,817 & 15,481 & & & 49,206 & 62,572 \\
\hline City Fixed Effects & YES & YES & YES & YES & NO & NO & NO & NO \\
\hline R-Squared & 0.64 & 0.67 & 0.67 & 0.67 & 0.03 & 0.07 & 0.07 & 0.07 \\
\hline
\end{tabular}




\section{Online Appendix (Not For Publication)}

Table A.10 - Effects of Having at Least One Direct Flight on the Maximum Price Difference (across All Goods) through an Airport within 100 Miles

\begin{tabular}{|c|c|c|c|c|c|c|c|c|}
\hline \multirow[t]{2}{*}{ Variables } & \multicolumn{8}{|c|}{ Dependent Variable: Maximum (across All Goods) of Absolute Log Price Difference between Cities } \\
\hline & $(1)$ & $(2)$ & (3) & (4) & (5) & (6) & (7) & (8) \\
\hline Number of Direct Flights & $\begin{array}{c}-0.02 * * * \\
(0.00) \\
{[0.00]}\end{array}$ & $\begin{array}{c}-0.01 * * * \\
(0.00 \\
{[0.00]}\end{array}$ & & $\begin{array}{c}-0.01 * * * \\
(0.00) \\
{[0.00]}\end{array}$ & $\begin{array}{c}-0.03 * * * \\
(0.00) \\
{[0.00]}\end{array}$ & $\begin{array}{c}-0.01 * * * \\
(0.00) \\
{[0.00]}\end{array}$ & & $\begin{array}{c}-0.01 * * * \\
(0.00) \\
{[0.00]}\end{array}$ \\
\hline Log Distance & & $\begin{array}{c}0.23^{* * *} \\
(0.00) \\
{[0.00]}\end{array}$ & $\begin{array}{c}0.21 * * * \\
(0.00) \\
{[0.00]}\end{array}$ & $\begin{array}{c}0.20 * * * \\
(0.00) \\
{[0.00]}\end{array}$ & & $\begin{array}{c}0.21^{* * *} \\
(0.00) \\
{[0.00]}\end{array}$ & $\begin{array}{c}0.21 * * * \\
(0.00) \\
{[0.00]}\end{array}$ & $\begin{array}{c}0.18 * * * \\
(0.00) \\
{[0.00]}\end{array}$ \\
\hline Border Dummy & & & $\begin{array}{c}0.31 * * * \\
(0.01) \\
{[0.00]}\end{array}$ & $\begin{array}{c}0.28 * * * \\
(0.01) \\
{[0.00]}\end{array}$ & & & $\begin{array}{c}0.51 * * * \\
(0.02) \\
{[0.00]}\end{array}$ & $\begin{array}{c}0.44 * * * \\
(0.02) \\
{[0.00]}\end{array}$ \\
\hline $\begin{array}{l}\text { Distance-Equivalent Effects } \\
\text { of One Direct Flight in Miles }\end{array}$ & & -155 & & -147 & & -286 & & -260 \\
\hline $\begin{array}{l}\text { Distance-Equivalent Effects } \\
\text { of Borders in Miles }\end{array}$ & & & 14,817 & 13,848 & & & 49,206 & 46,425 \\
\hline City Fixed Effects & YES & YES & YES & YES & NO & NO & NO & NO \\
\hline R-Squared & 0.64 & 0.67 & 0.67 & 0.67 & 0.03 & 0.07 & 0.07 & 0.08 \\
\hline
\end{tabular}

